\title{
The Best of Times, The Worst of Times:
}

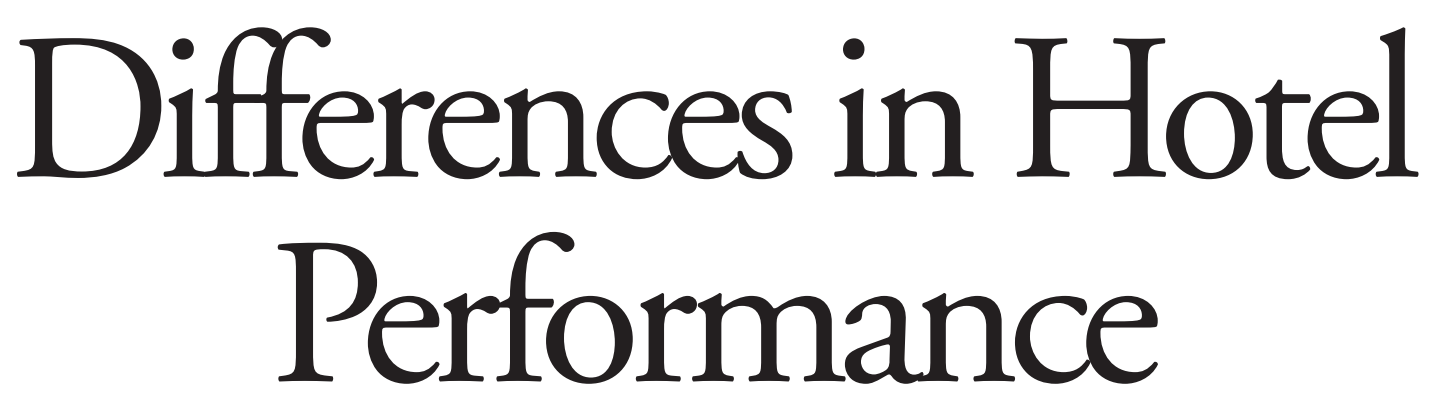

Following 9/11

Not all hotels participated equally in the recent industry plunge—brought on by both recession and terrorism—and not all are recovering at the same rate.

BY CATHY A. ENZ AND LINDA CANINA

By almost any measure the U.S. lodging industry as a whole was hard hit by the events of September 11, 2001. Demand forecasts released and revised in the closing weeks of 2001 indicated that the industry was experiencing the worst of times. ${ }^{1}$ Moreover, east-coast news media and commentators projected the devastating effects felt in New York, Washington, D.C., and other eastern cities on the entire nation. Some

\footnotetext{
${ }^{1}$ See: "A Business in Search of Customers," The Economist, September 29, 2001; "The Travel and Tourism Industry Hammered Hard in Wake of September 11 Attack," Travel Business Roundtable, November 15, 2001. Also see: "Hotel Valuation," by John O’Neill and Anne Jones, on pp. 5364 of this Cornell Quarterly.

(C) 2002, CORNELL UNIVERSITY
}

experts were careful to observe that the unarguably huge influence on the industry was not affecting all hotel types, all states, or all cities in equal measure, but most analysts were sounding an alarm. Particularly hard hit were luxury hotels in major cities, while those in secondary and tertiary markets reported a more muted effect. In all of this we found little attention being given to just which hotels were hurt the most and, indeed, whether any areas of the country were unscathed or even prospering.

In this article we seek to make that comparison. Using revenue per available room (RevPAR), the most universally accepted measure for overall hotel operating performance, this article chronicles how the 9/11 tragedy has affected hotels' 
EXHIBIT 1

\section{Year-to-year change in RevPAR}

\begin{tabular}{ccc} 
Year & RevPAR & Annual change \\
\hline 1990 & 43.14 & $-2.92 \%$ \\
1991 & 41.14 & $-4.63 \%$ \\
1992 & 40.65 & $-1.20 \%$ \\
1993 & 41.67 & $2.52 \%$ \\
1994 & 43.03 & $3.25 \%$ \\
1995 & 44.04 & $2.35 \%$ \\
1996 & 44.56 & $1.17 \%$ \\
1997 & 44.89 & $0.74 \%$ \\
1998 & 45.59 & $1.56 \%$ \\
1999 & 45.71 & $0.27 \%$ \\
2000 & 46.90 & $2.61 \%$ \\
2001 & 43.45 & $-7.35 \%$
\end{tabular}

operating performance in various parts of the United States. We begin by placing the year-2001 operating statistics in historical context, and then we compare RevPAR performance by region, population center, state, and selected key city. Our analysis seeks to determine which hotels and regions were hardest hit by the events of 9/11 and which areas of the United States may have escaped serious business drop offs. Finally, the early months of 2002 are included in the analysis to permit a preliminary glimpse at the prospects for recovery, based on monthly performance up through the second quarter of 2002 .

\section{A Decade of Performance}

To begin our exploration of industry performance we calculated the mean (i.e., average) RevPAR for U.S. hotels from 1990 through 2001 along with the year-to-year percentage change in RevPAR, as shown in Exhibit $1 .^{2}$ Unlike an industry-based measure of RevPAR that takes total U.S. hotel revenues divided by the number of rooms available for sale, our measures are cre-

\footnotetext{
${ }^{2}$ This paper is based on data provided by Smith Travel Research through a strategic alliance with the Center for Hospitality Research at Cornell University's School of Hotel Administration.
}

ated by taking the revenue for each hotel and dividing that figure by the number of rooms available at that hotel for sale and then averaging all hotels in the sample to get a mean RevPAR. The value of our approach is that we are examining average hotel RevPAR performance, not overall industry performance. ${ }^{3}$

As Exhibit 1 shows, not since 1991 has the industry experienced a year-to-year RevPAR drop, as it did from 2000 to 2001. Moreover, although the 1990-92 recession saw steeply declining RevPAR, that drop was smaller than the 7.35-percent decline recorded from 2000 to 2001. The industry saw record performance in 2000 with a RevPAR of $\$ 46.90$, but the 2001 figure of $\$ 43.45$ harkened back to 1994's level of $\$ 43.03$. We believe that we can conclude without dispute that 2001 was a disastrous year for lodging performance. That said, however, a careful analysis of the data shows that both economic factors and the 9/11 events were responsible. To demonstrate that point, we compare hotels' performance across various regions, population centers, states, and cities.

\section{Regional Variations}

Our analysis found that the regions with the hottest economies and the highest RevPARs also had the farthest to fall. As shown in Exhibit 2, three regions stand out as the highest RevPAR performers in 2000 - namely, New England, the middle Atlantic, and the Pacific. Historically, those regions have been the most volatile-responding most strongly both to good and bad times. During good times they have had the largest positive percentage change in RevPAR—as occurred in the 1996-2000 period-and during bad times they have had the largest negative percentage change-as occurred, for instance, in 1991 and again in 2001.

\footnotetext{
${ }^{3}$ The advantage of employing this approach is that the RevPARs reflect the summation of individual hotels' performance and not the more aggregate industry-level performance. As we have found in previous performance studies, given the huge variation in performance in hotels, the industry-level measures may not show the variation in hotel performance. See: Cathy Enz, Linda Canina, and Kate Walsh, "Hotel-industry Averages: An Inaccurate Tool for Measuring Performance," Cornell Hotel and Restaurant Administration Quarterly, Vol. 42, No. 6 (December 2001), pp. 22-32.
} 


\section{Percentage change in RevPAR by region}

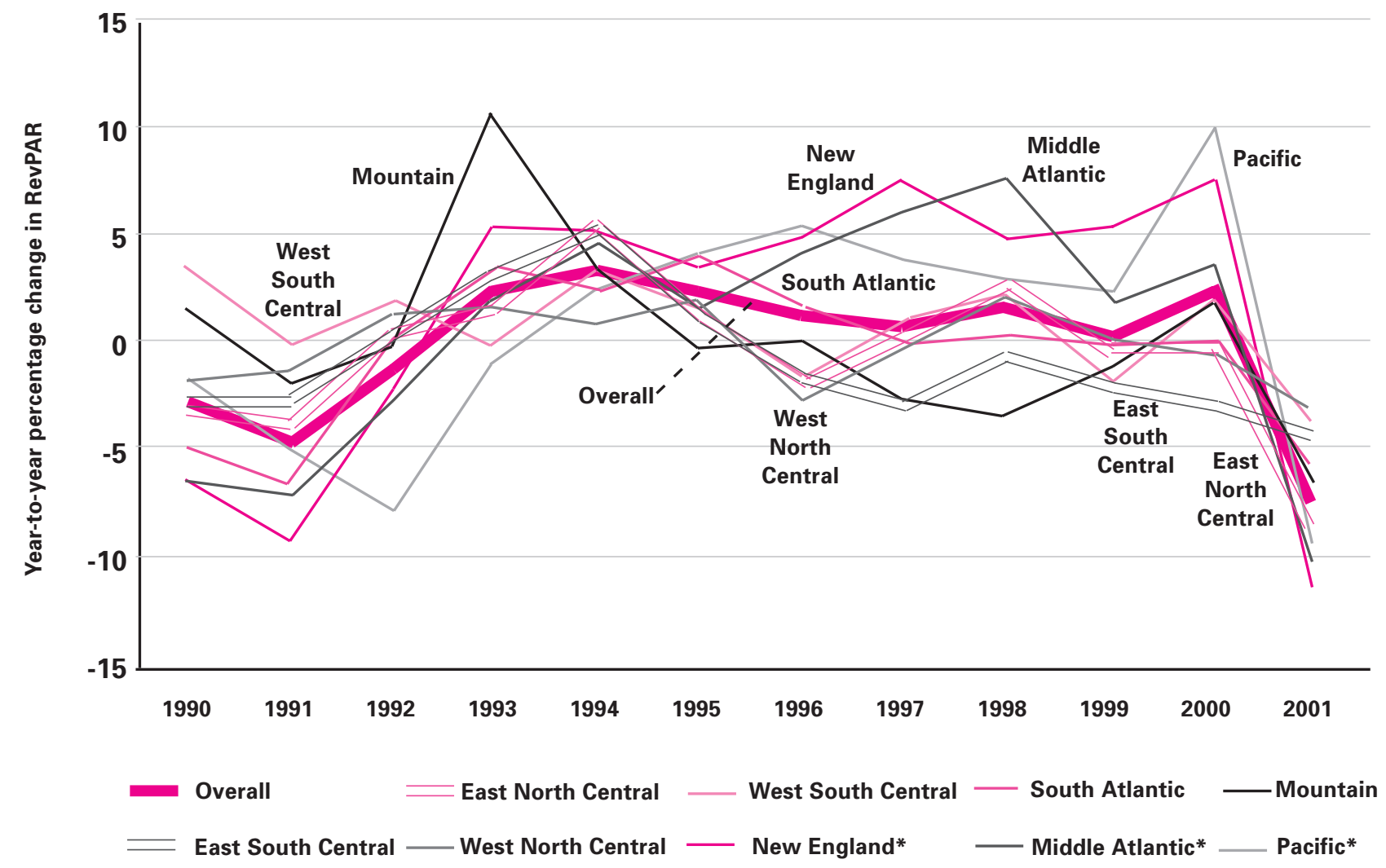

*These three regions (New England, Middle Atlantic, Pacific) endured the largest drop in average RevPAR.

Not surprisingly, then, these same three regions were the most negatively affected by the events of 9/11. The change in annual RevPAR from 2000 to 2001 was -10.30 percent for the New England region, -9.50 percent for the middle Atlantic region, and -9.27 percent for the Pacific region (again, see Exhibit 2).

These three hardest-hit regions (which had the highest RevPARs) were also the regions with the greatest degree of variability in performance among the hotels (and destinations) within the region during the current period. Thus, it is difficult to make broad generalizations even with regard to those three regions. The standard deviation of RevPAR was $\$ 51.16$ for the three hardest-hit regions versus a standard deviation of $\$ 36.28$ for the other six regions. The RevPAR levels for each region are shown in Exhibit 3, 


\section{EXHIBIT 3}

\section{RevPAR by region for 1990-2001}

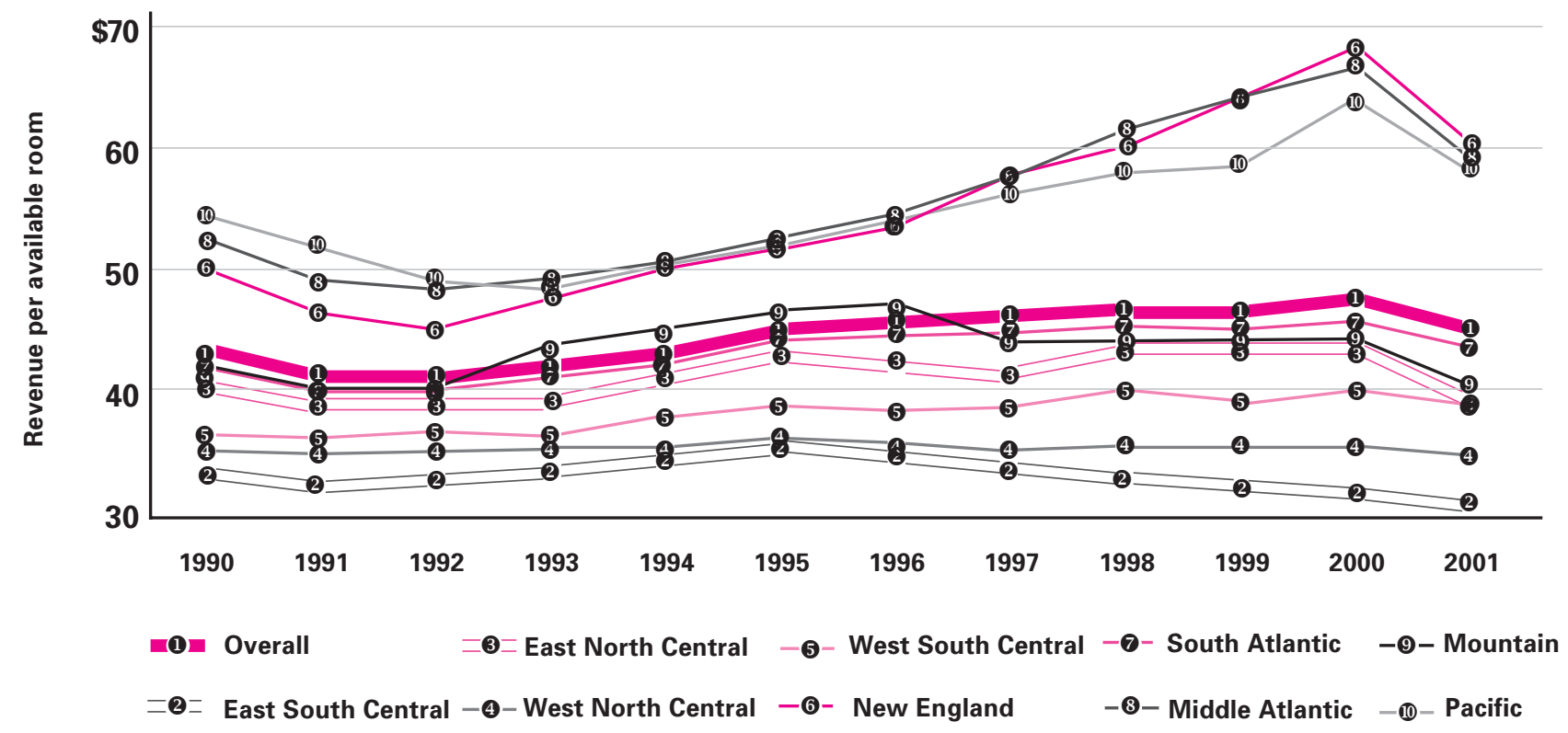

which depicts regional RevPAR fluctuations for the years 1990-2001.

The year-to-year performance drops in the fourth quarter of 2001 (shown in Exhibit 4) further reveal the effects of $9 / 11$, as the New England region experienced a -19.1 percent change, while the middle Atlantic regions experienced an -18.4-percent decline and the Pacific region fell off -21.8 percent. The graph also shows that these regions' RevPAR was already falling in the third quarter of 2001 (-15.29 percent for New England, -12.45 for the middle Atlantic, and -14.66 for the Pacific). Indeed, year-to-year RevPAR for the industry as a whole had dropped 10 percent in the third quarter of 2001 . This provides an indication that economic conditions together with the events of 9/11 were the factors behind the large percentage drop in RevPAR in the hardhit regions for the fourth quarter of 2001.
Bounceback. In keeping with past performance, though, by the second quarter of 2002 each of the regions had made a remarkable recovery from the nadir of the fourth quarter of 2001. Even so, only two regions (east south central and west north central) showed year-to-year improvement (i.e., from the second quarter of 2001). For the east-south-central region, the RevPAR was $\$ 36.20$ for the second quarter of 2002 compared to $\$ 35.03$ for 2001's second quarter. For the west-north-central region, the RevPAR was $\$ 41.40$ for the second quarter of 2002 versus $\$ 40.22$ for the year earlier.

Part of the recovery story is that the east-northcentral region was apparently ahead of other regions in experiencing a RevPAR decline in 2001, with noteworthy first- and second-quarter declines in (year-to-year) performance. Indeed, by the second quarter of 2001 all regions were ex- 


\section{Regional performance by quarters, 2001-02}

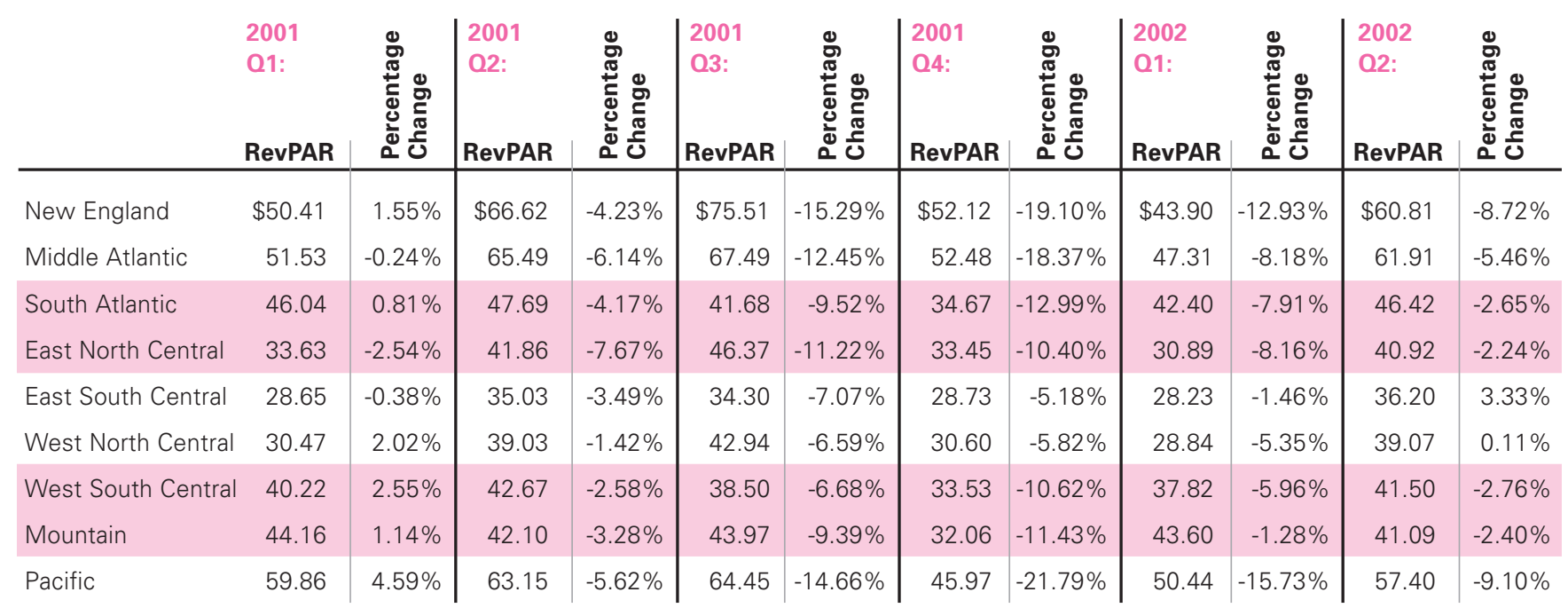

periencing a falling economy, and then the $9 / 11$ events magnified that decline. At this writing the Pacific region continues to struggle, while New England and the middle Atlantic have recovered somewhat.

Comparing the performance of the three hardest-hit regions with the results from the other six also revealed significant statistical differences. Statistical tests revealed that compared to other regions the mean change in RevPAR in the fourth quarter of 2001 was significantly greater for $\mathrm{New}$ England, the middle Atlantic, and the Pacific regions ${ }^{4}$ while the other six regions were more similar in their performance. The magnitude of these differences in RevPAR performance strongly suggests both economic factors and 9/11 as the causes for decline.

The monthly pattern of performance from 1999 through June 2002 shows clearly that the

\footnotetext{
${ }^{4}$ The test for significant differences revealed an F-value of 23.90 , significant at a $p$-value of .0001 for the differences among the three high revenue regions compared to the six remaining regions. A total of 20,054 hotels' percentage change in RevPAR performance were included to conduct this statistical test.
}

9/11 events affected the hard-hit regions' performance more profoundly than it shaped other regions of the country, as Exhibit 5 and Exhibit 6 highlight (overleaf). The central regions show modest alterations in RevPAR (whether descending or ascending), leading to the conclusion that economic factors and not 9/11 are the cause of the revenue changes for hotels in those regions. Though it was relatively steady, the east-south-central region was consistently the lowest RevPAR performer. On the other hand, the sudden, steep decline for eastand west-coast regions seems to indicate that these areas- though also affected by the recession-were most profoundly affected by the events of $9 / 11$.

As we said above, the standard deviation for the hardest-hit regions indicates steep differences within those regions. For that reason, we needed a finer focus to determine where 9/11's effects were felt most keenly. In particular, our state-bystate analysis looked at key states in the hard-hit regions_namely, Massachusetts (New England), New York (middle Atlantic), and California (Pacific). 


\section{EXHIBIT 5}

Monthly RevPAR by region, January 1999-May 2002

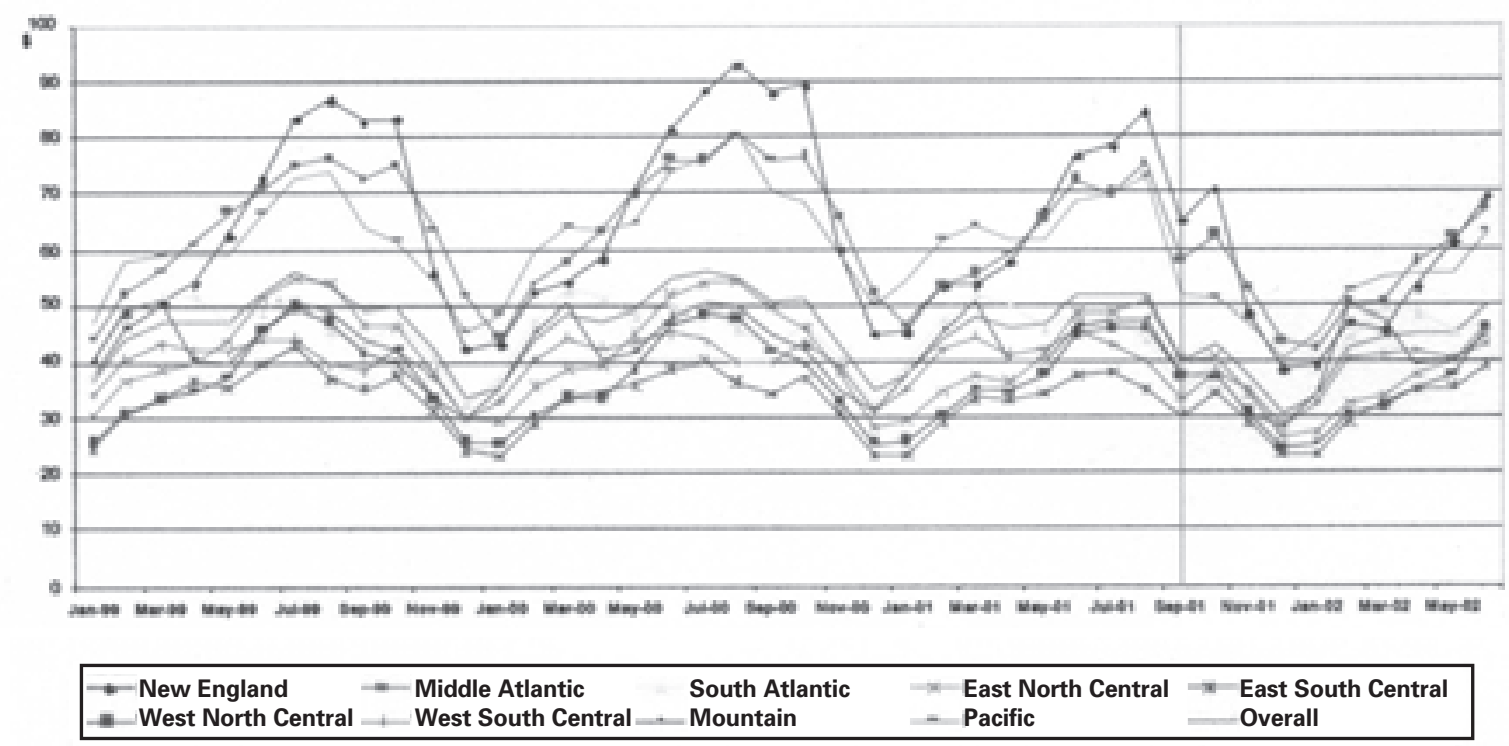

\section{EXHIBIT 6}

Monthly year-to-year percentage RevPAR change by region, January 1999-May 2002

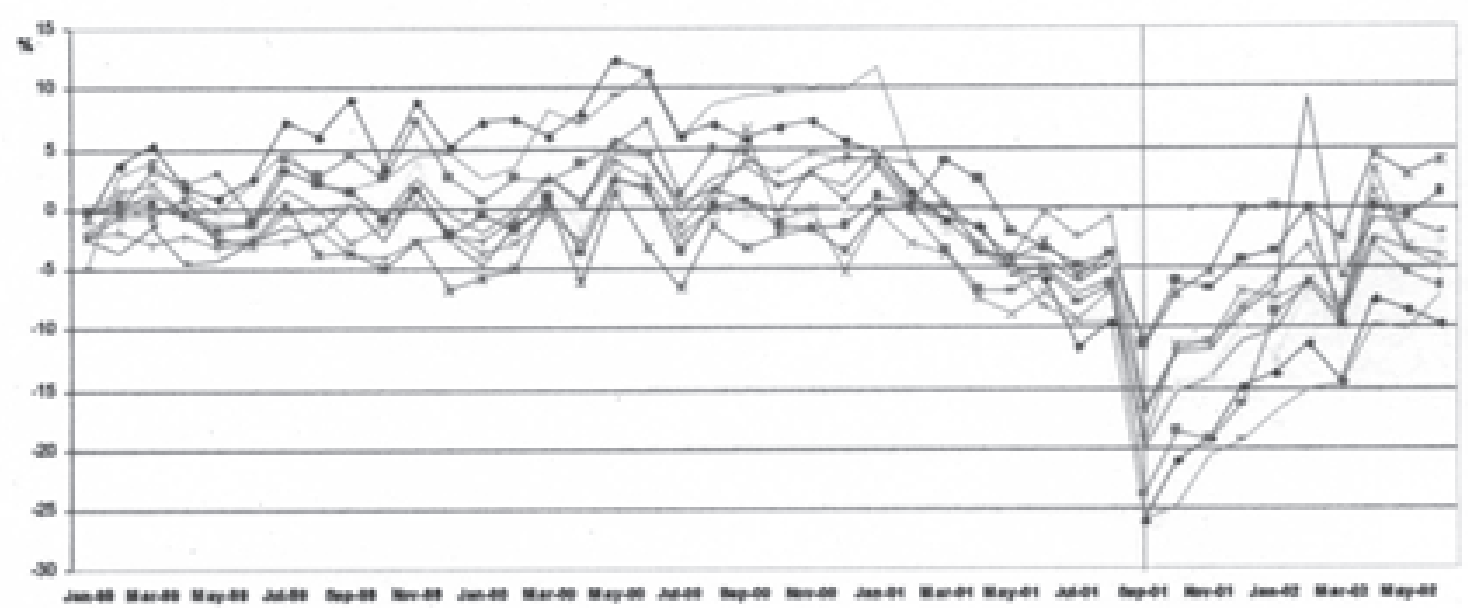

\begin{tabular}{|c|c|c|}
\hline 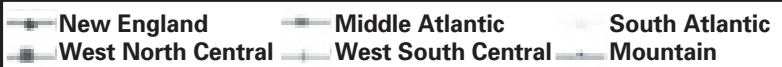 & $\begin{array}{l}\text { East North Central } \\
\text { - Pacific }\end{array}$ & $\begin{array}{l}* \text { East South Central } \\
\quad \text { Overall }\end{array}$ \\
\hline
\end{tabular}




\section{Hard-hit and Well-missed States}

Our analysis made it clear that not all hotels suffered performance failures due to the $9 / 11$ events (even if those hotels are experiencing lower RevPARs, as may well be the case). When comparing year-to-year percentage changes in annual RevPAR for each state, the data show clearly that Massachusetts, New York, Illinois, California, and North Carolina (in that order) experienced substantial declines in 2001. At the other extreme were Oklahoma, Wyoming, and North Dakotastates in which hotels actually performed better in 2001 than in 2000. West Virginia and Idaho followed after those three states with RevPAR declines of less than 1 percent. A close look at Exhibit 7 would suggest overall that states where hotels generally have relatively low average RevPARs were not as hard hit as were those states where hotels enjoy high RevPAR values. Once again, then, hotels that were doing the best in 2000 had the farthest to fall in 2001. It also appears that less-populous states fared better than heavily populated areas (a subject we will discuss later in the paper), perhaps because of their greater reliance on regional travel and less dependence on airlines as a major mode of travel transportation.

While the year-to-year data reveal those states that experienced RevPAR declines in 2001, those results might just as easily be attributed to recession as to $9 / 11$. To distinguish recessionary effects from those directly emanating from the terrorist attacks we turn to changes in the fourth quarter of 2001. Exhibit 8 (on the next page) restates the list in Exhibit 7 by showing the ten states hardest hit in the fourth quarter of 2001. The analysis shows that Washington, D.C., and Hawaii emerge as hard-hit areas, while the results for Illinois and North Carolina seem recessionary. The three populous states- $\mathrm{New}$ York, Massachusetts, and California-remain at the top of the list of states hardest hit (no surprise, since they are the largest states in their hardhit regions). Once again, these states, usually high fliers in good times, are typically hardest hit in bad times.

Hotels in five states actually improved their year-to-year performance in the fourth quarter of 2001. In addition to North Dakota and Okla-
EXHIBIT 7

Performance by state, 2001: full year and fourth quarter

\begin{tabular}{|c|c|c|c|c|}
\hline \multirow[b]{2}{*}{ State } & \multicolumn{2}{|c|}{ Full-year 2001} & \multicolumn{2}{|c|}{ Fourth quarter 2001} \\
\hline & $\begin{array}{c}\text { Percentage } \\
\text { change }\end{array}$ & RevPAR & $\begin{array}{l}\text { Percentage } \\
\text { change }\end{array}$ & RevPAR \\
\hline Massachusetts & $-15.55 \%$ & $\$ 70.26$ & $-29.11 \%$ & $\$ 56.49$ \\
\hline New York & $-13.51 \%$ & 73.41 & $-24.17 \%$ & 65.43 \\
\hline Illinois & $-10.87 \%$ & 44.89 & $-15.53 \%$ & 39.36 \\
\hline California & -10.33 & 60.95 & $-23.73 \%$ & 47.89 \\
\hline North Carolina & $-8.58 \%$ & 34.42 & $-11.38 \%$ & 30.93 \\
\hline Ohio & $-8.52 \%$ & 34.99 & $-8.35 \%$ & 29.63 \\
\hline Michigan & $-8.18 \%$ & 41.64 & $-11.66 \%$ & 34.42 \\
\hline Colorado & $-7.59 \%$ & 45.87 & $-13.71 \%$ & 32.81 \\
\hline Hawaii & $-7.32 \%$ & 95.54 & $-21.85 \%$ & 76.34 \\
\hline Louisiana & $-7.23 \%$ & 47.38 & $-16.06 \%$ & 41.92 \\
\hline Nevada & $-7.16 \%$ & 38.95 & $-18.78 \%$ & 31.74 \\
\hline Delaware & $-7.02 \%$ & 48.36 & $-8.91 \%$ & 42.14 \\
\hline New Jersey & $-6.99 \%$ & 62.43 & $-18.24 \%$ & 53.22 \\
\hline Connecticut & $-6.89 \%$ & 55.94 & $-12.59 \%$ & 49.59 \\
\hline Washington, D.C. & $-6.81 \%$ & 101.62 & $-24.69 \%$ & 77.57 \\
\hline Minnesota & $-6.69 \%$ & 43.44 & $-12.43 \%$ & 35.77 \\
\hline Kentucky & $-6.64 \%$ & 31.82 & $-6.10 \%$ & 28.66 \\
\hline Georgia & $-6.42 \%$ & 35.20 & $-10.09 \%$ & 30.60 \\
\hline Washington & $-6.36 \%$ & 45.76 & $-16.29 \%$ & 35.04 \\
\hline Arizona & $-6.31 \%$ & 43.33 & $-15.38 \%$ & 36.62 \\
\hline Indiana & $-6.06 \%$ & 35.36 & $-3.85 \%$ & 31.80 \\
\hline Wisconsin & $-6.00 \%$ & 35.79 & $-6.49 \%$ & 30.67 \\
\hline South Carolina & $-5.92 \%$ & 34.92 & $-6.95 \%$ & 28.36 \\
\hline Rhode Island & $-5.66 \%$ & 74.49 & $-6.81 \%$ & 62.08 \\
\hline Tennessee & $-5.41 \%$ & 32.40 & $-6.62 \%$ & 30.49 \\
\hline Virginia & $-5.01 \%$ & 43.80 & $-11.28 \%$ & 35.52 \\
\hline Oregon & $-4.78 \%$ & 36.98 & $-9.17 \%$ & 29.75 \\
\hline Pennsylvania & $-4.71 \%$ & 45.70 & $-7.23 \%$ & 40.54 \\
\hline Florida & $-4.66 \%$ & 49.15 & $-17.54 \%$ & 36.95 \\
\hline Maryland & $-4.43 \%$ & 54.83 & $-10.07 \%$ & 45.17 \\
\hline lowa & $-4.16 \%$ & 31.89 & $-5.55 \%$ & 27.94 \\
\hline Texas & $-4.13 \%$ & 39.66 & $-11.46 \%$ & 33.52 \\
\hline Alaska & $-3.88 \%$ & 65.74 & $3.06 \%$ & 40.49 \\
\hline Missouri & $-3.86 \%$ & 35.42 & $-5.81 \%$ & 31.56 \\
\hline Mississippi & $-3.18 \%$ & 30.30 & $-4.29 \%$ & 26.00 \\
\hline New Hampshire & $-3.16 \%$ & 54.24 & $-3.34 \%$ & 50.38 \\
\hline Vermont & $-2.97 \%$ & 51.59 & $-7.36 \%$ & 48.73 \\
\hline Nebraska & $-2.78 \%$ & 31.93 & $0.91 \%$ & 27.06 \\
\hline South Dakota & $-2.57 \%$ & 33.58 & $-1.89 \%$ & 23.91 \\
\hline Kansas & $-2.42 \%$ & 34.78 & $-2.83 \%$ & 31.42 \\
\hline Maine & $-2.37 \%$ & 49.42 & $-9.07 \%$ & 38.81 \\
\hline Arkansas & $-2.21 \%$ & 30.86 & $-6.58 \%$ & 28.05 \\
\hline Montana & $-2.00 \%$ & 34.25 & $0.55 \%$ & 24.71 \\
\hline Utah & $-1.86 \%$ & 35.24 & $-5.82 \%$ & 26.96 \\
\hline New Mexico & $-1.79 \%$ & 36.61 & $-2.49 \%$ & 33.15 \\
\hline Alabama & $-1.53 \%$ & 31.10 & $-2.03 \%$ & 27.89 \\
\hline Idaho & $-0.79 \%$ & 38.57 & $-7.90 \%$ & 28.15 \\
\hline West Virginia & $-0.67 \%$ & 32.88 & $-2.31 \%$ & 30.10 \\
\hline North Dakota & $0.12 \%$ & 30.38 & $8.25 \%$ & 28.16 \\
\hline Wyoming & $0.80 \%$ & 41.55 & $-9.64 \%$ & 24.25 \\
\hline Oklahoma & $1.94 \%$ & 30.70 & $1.80 \%$ & 28.22 \\
\hline
\end{tabular}




\section{EXHIBIT 8}

\section{Ten states with greatest RevPAR drop in the fourth quarter of 2001}
(1) Massachusetts
(2) District of Columbia
(3) New York
(4) California
(5) Hawaii
(6) Nevada
(7) New Jersey
(8) Washington
(9) Louisiana
(10) Illinois

EXHIBIT 9

\section{Ten states with the best performance in the} fourth quarter of 2001
(1) North Dakota
(2) Alaska
(3) Oklahoma
(4) Nebraska
(5) Montana
(6) Alabama
(7) West Virginia
(8) New Mexico
(9) Kansas
(10) New Hampshire

mance gains, the next five least-hard-hit states showed performance declines of under 3.5 percent.

Four of the five hardest-hit states continue to show only slow progress toward recovery after the second quarter of 2002, with the exception of New York, which seems to be recovering faster than most. By mid-year 2002 several states showed worse year-to-year results than did New York. Nevada, New Jersey, Florida, Washington, Illinois, Connecticut, Minnesota, and Michigan all reported worse annual RevPAR declines than did New York's hotels. Because the economic health of any state is linked to its centers of commerce, examining the situation in key metropolitan areas may be helpful in understanding the uneven results for hotels after 9/11.

\section{The Population Problem}

As we said above, it appears that the states most affected by the events of $9 / 11$ are those with large population centers - and not just New York and Washington, D.C. To test whether there are systematic differences in RevPAR performance of hotels across regions' various population sizes, we categorized metropolitan statistical areas (MSAs) into four population-size quartiles using the most recently available regional accounts data from the U.S. Bureau of Economic Analysis. ${ }^{5}$

The analysis by population size reveals the same pattern as that found for regions and states. During bad times, namely 1991 and the fourth quarter of 2001, the percentage change in RevPAR was the most negative for hotels located in the highest-population quartile (i.e., MSAs with a population of at least 663,865; see Exhibit 10). While these large population centers are hardest hit in bad times, they also enjoy the most favorable outcomes of good times (notably, 19962000; see Exhibit 11-overleaf). Performance volatility, defined as substantial performance variations, also appears strongest in large metropolitan areas.

\footnotetext{
${ }^{5}$ The quartiles were formed based on the distribution of population densities by metropolitan statistical areas (MSAs) for the year 2000. For example, the upper limit of the lowest quartile is the 25 th percentile of the distribution, and the lower limit of the highest quartile is the 75 th percentile of the distribution. The 2000 regional accounts data from the Bureau of Economic Analysis can be found at www.bea.gov/bea/regional/reis/.
} 


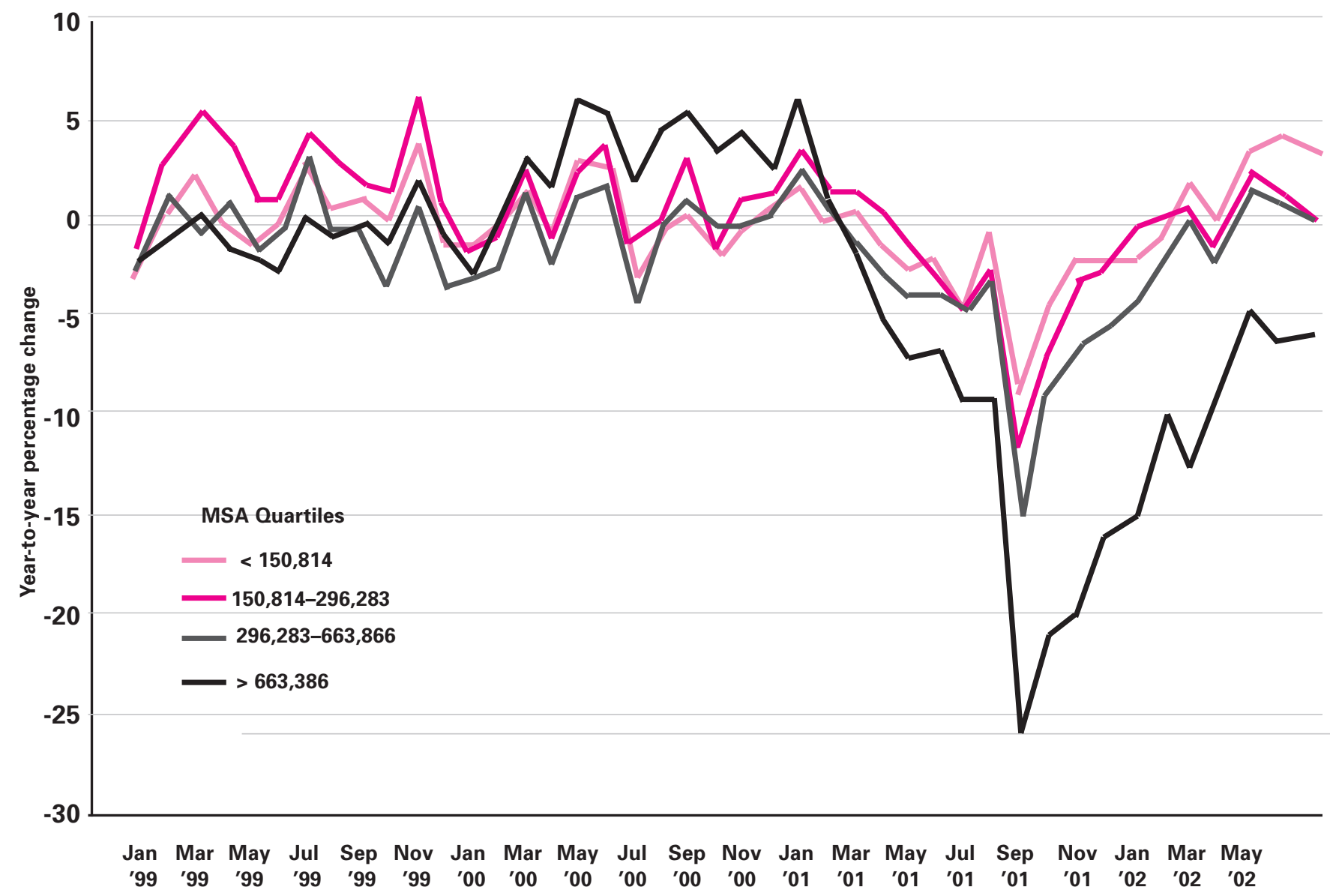

To continue that thread, examining metropolitan areas by population, we found that the highest population areas are located in the regions and the states that were the hardest hit during the recent downturn. For example, Los Angeles and New York each have about nine million residents, and Boston is not far behind, with six million. (Although we did not examine the Windy City, add Chicago to that list and you have the four largest metropolitan populations in the entire United States.) Because we suspect that these big cities are the "tail that wags the dog" for their regions, our final analysis compares the RevPAR results in three of the most-populous cities with those of other metropolitan areas in the hardesthit states.

\section{Exploring Key Cities}

The results of our analysis of hotel results for key cities within the five hardest-hit states are shown in Exhibit 12 (overleaf). In California eight cities had RevPAR declines of over 20 percent, led by San Jose, which reported a fourth-quarter drop of 46.77 percent from the same quarter of 2000 . 


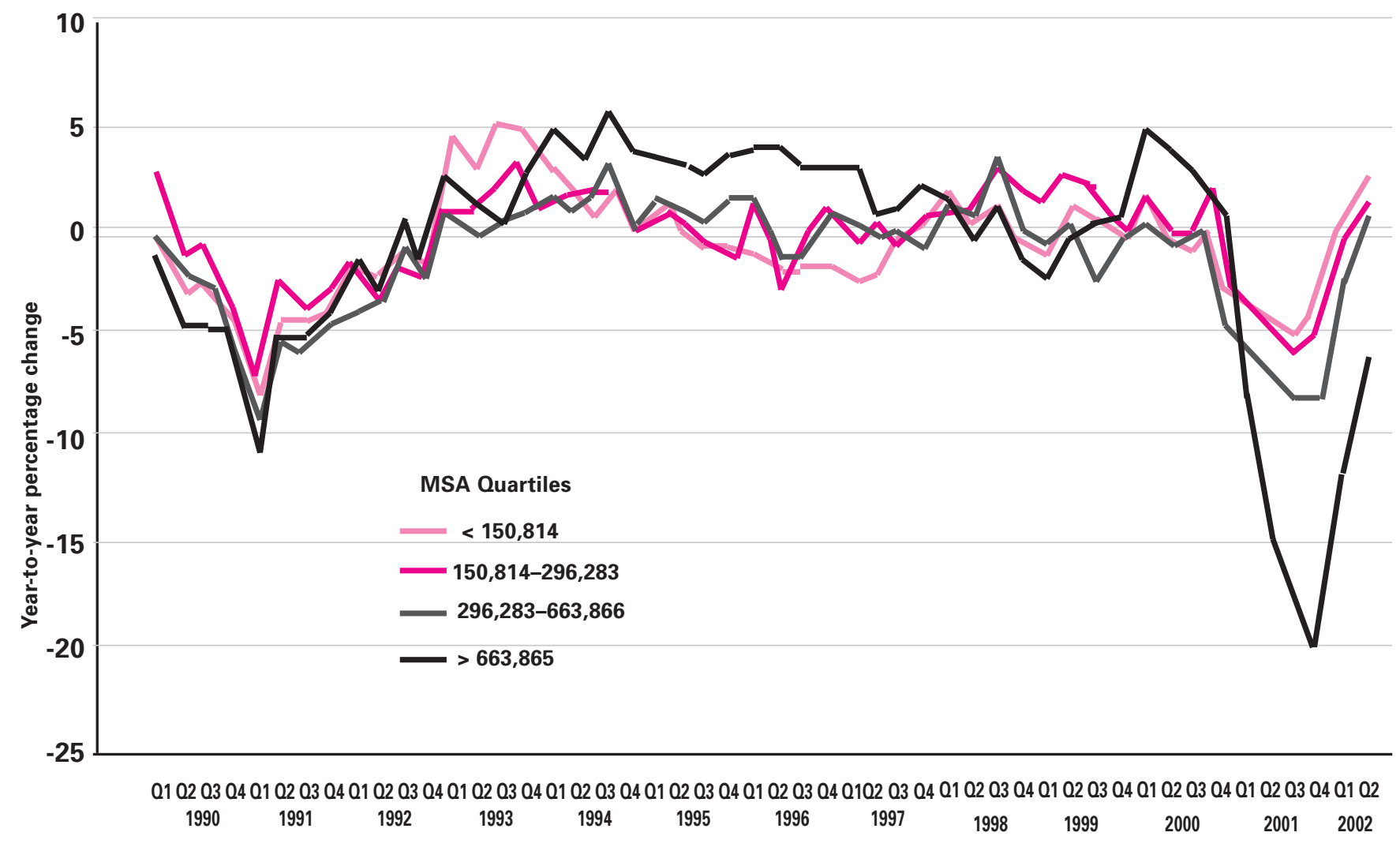

San Francisco, Santa Cruz, Oakland, and Santa Rosa were also hard hit. Those San Francisco Bay-area cities felt the combined effects of the national recession, failing dot-com businesses, and (apparently) the 9/11 attacks. The poor statewide results for New York and Massachusetts clearly stemmed from the declines in New York City and Boston. Upstate and suburban New York markets saw much less effect from 9/11 than did the city itself. Hawaii is a special case, owing to its dependence on the number of airline seats arriving on the islands. Given the airlines' turmoil, the lack of alternatives to air travel was particularly punishing for Honolulu. When that fac- tor is combined with what we believe is a temporarily diminished enthusiasm for holiday leisure travel, the result was a 30-percent RevPAR decline in Honolulu.

Exhibit 13 (overleaf) lists the top ten cities that were hardest hit in the fourth quarter of 2001. In descending order they are San Jose, San Francisco, New York, Boston, Oakland, Miami, Austin, Orlando, Dallas, and Las Vegas. Two of those cities are leisure-travel-oriented destinations_-Las Vegas and Orlando-that certainly felt a double whammy as the sudden drop in both domestic and international travel after 9/11 compounded the effects of the recession. 
Each of these major markets seems to be on its own recovery track (or lack thereof). Overall performance is encouraging, but reveals that each of these cities is facing an uphill battle to return to their earlier prosperity. Fluctuations in RevPAR dollars between the last quarter of 2001 and the early part of 2002 were most dramatic for the cities of Miami, New York, Boston, and San Francisco. At the same time, San Jose and San Francisco are clearly experiencing the slowest recovery in 2002. The average percentage change in quarterly RevPAR for all cities in the second quarter of 2002 was about a 4 percent drop, which is in marked contrast to the 15 percent drop for these 10 cities alone.

The percentage drop in RevPAR for the average property (in our total sample) was about 11 percent for the third quarter of 2001, 14 percent for the fourth quarter of that year, 8 percent for the first quarter of 2002, and 4 percent for the second quarter of 2002. For those same quarters, the comparative figures for the ten hardesthit cities combined were -23 percent, -33 percent, -24 percent, and -16 percent. Thus, even though these cities' performance is improving they are still far below the average. On the other hand, we selected another bundle of cities with below-average performance, (i.e., Atlanta, Chicago, Cleveland, Memphis, and Tucson) and found that their hotels were still doing better than the worst-off cities. Combined RevPAR drops for those five cities from the third quarter of 2001 to the fourth quarter of 2001 was 14 percent; from the fourth quarter to the first quarter of 2002, 15 percent; and from the first quarter to the second quarter of 2002,7 percent.

\section{What Comes Next?}

Past performance has shown the U.S. lodging industry's resilience. Despite much pain, the industry recovered well from the sharp recession and war in 1991-not to mention the selfinflicted problem of over-leveraged hotel deals. ${ }^{6}$ Earlier than that, when oil prices became unstable in the 1970s, the industry restructured and

\footnotetext{
${ }^{6}$ For example, see: Glenn Withiam, "Back to Life: Many Hotels' Performance Improves," Cornell Hotel and Restaurant Administration Quarterly, Vol. 34, No. 5 (October 1993), p. 16.
}

\section{EXHIBIT 12}

Performance in metro areas of hardest-hit states, 2001: fourth quarter

\begin{tabular}{|c|c|c|c|}
\hline Metro area & $\begin{array}{l}\text { Population } \\
\text { (000s) }\end{array}$ & RevPAR & $\begin{array}{c}\text { Percentage } \\
\text { change }\end{array}$ \\
\hline \multicolumn{4}{|l|}{ California } \\
\hline San Jose & 1,683 & $\$ 54.35$ & $-46.77 \%$ \\
\hline San Francisco & 1,731 & 59.84 & $-42.49 \%$ \\
\hline Santa Cruz-Watsonville & 256 & 37.33 & $-33.15 \%$ \\
\hline Oakland & 2,402 & 51.76 & $-30.07 \%$ \\
\hline Santa Rosa & 460 & 43.96 & $-25.69 \%$ \\
\hline Stockton-Lodi & 568 & 36.64 & $-24.51 \%$ \\
\hline Modesto & 450 & 34.34 & $-24.51 \%$ \\
\hline Los Angeles-Long Beach & 9,546 & 49.76 & $-23.05 \%$ \\
\hline Orange County & 2,856 & 41.80 & $-17.85 \%$ \\
\hline San Diego & 2,825 & 52.30 & $-16.41 \%$ \\
\hline Salinas & 403 & 65.07 & $-12.97 \%$ \\
\hline Merced & 212 & 30.69 & $-10.83 \%$ \\
\hline Santa Barbara-Santa Maria & 400 & 64.12 & $-8.20 \%$ \\
\hline Vellejo-Fairfield-Napa & 522 & 59.18 & $-7.53 \%$ \\
\hline Sacramento & 1,638 & 44.09 & $-7.24 \%$ \\
\hline Ventura & 757 & 43.65 & $-5.82 \%$ \\
\hline Riverside-San Bernadino & 3,280 & 41.77 & $-3.61 \%$ \\
\hline San Luis Obispo-Atascado & 247 & 49.55 & $-1.30 \%$ \\
\hline Yolo & 170 & 33.37 & $1.46 \%$ \\
\hline Bakersfield & 664 & 31.86 & $3.37 \%$ \\
\hline Visalia-Tualare-Porterville & 369 & 28.83 & $3.78 \%$ \\
\hline Fresno & 926 & 31.98 & $9.69 \%$ \\
\hline Yuba City & 140 & 37.61 & $10.91 \%$ \\
\hline Redding & 164 & 37.35 & $12.95 \%$ \\
\hline Chico-Paradise & 204 & 30.96 & $15.23 \%$ \\
\hline \multicolumn{4}{|c|}{ District of Columbia and vicinity } \\
\hline Washington, D.C. & 4,948 & 77.57 & $-24.69 \%$ \\
\hline \multicolumn{4}{|l|}{ Hawaii } \\
\hline Honolulu & 875 & 54.88 & $-30.13 \%$ \\
\hline \multicolumn{4}{|l|}{ Massachusetts } \\
\hline Boston-Worcester-Lawrence & 6,067 & 59.59 & $-33.24 \%$ \\
\hline Barnstable-Yarmouth & 223 & 36.09 & $-9.99 \%$ \\
\hline Springfield & 609 & 39.36 & $-7.26 \%$ \\
\hline Pittsfield & 135 & 62.06 & $2.98 \%$ \\
\hline
\end{tabular}

\section{New York}

$\begin{array}{lcrr}\text { New York } & 9,322 & 128.35 & -35.92 \% \\ \text { Elmira } & 91 & 28.00 & -14.39 \% \\ \text { Buffalo-Niagara Falls } & 117 & 30.43 & -12.55 \% \\ \text { Nassau and Suffolk Counties } & 276 & 75.08 & -10.55 \% \\ \text { Jamestown } & 140 & 27.12 & -10.39 \% \\ \text { Utica-Rome } & 299 & 34.77 & -9.10 \% \\ \text { Rochester } & 1,098 & 35.24 & -8.66 \% \\ \text { Glens Falls } & 124 & 28.23 & -6.54 \% \\ \text { Syracuse } & 732 & 35.44 & -1.27 \% \\ \text { Dutchess County } & 281 & 64.38 & 0.28 \% \\ \text { Newburgh } & 390 & 51.10 & 2.46 \% \\ \text { Binghamton } & 252 & 33.80 & 3.02 \% \\ \text { Albany-Schenectady-Troy } & 876 & 46.65 & 3.74 \%\end{array}$




\section{EXHIBIT 13}

\section{Top ten hardest-hit cities}

\begin{tabular}{|c|c|c|c|c|c|c|}
\hline Metro area & $\begin{array}{l}2001 \\
\text { Q4 } \\
\text { RevPAR }\end{array}$ & 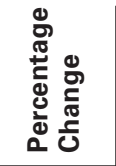 & $\begin{array}{l}2002 \\
\text { Q1 } \\
\text { RevPAR }\end{array}$ & 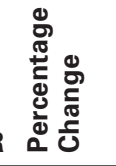 & $\begin{array}{l}2002 \\
\text { Q2 } \\
\text { RePAR }\end{array}$ & 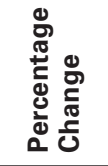 \\
\hline Austin-San Marcos & $\$ 36.55$ & $-29.93 \%$ & $\$ 40.89$ & $-25.22 \%$ & $\$ 46.94$ & $-12.79 \%$ \\
\hline Boston-Worcester-Lawrence & 59.59 & $-33.24 \%$ & 50.00 & $-24.31 \%$ & 73.08 & $-16.99 \%$ \\
\hline Dallas & 33.48 & $-25.58 \%$ & 38.38 & $-17.88 \%$ & 40.15 & -8.54 \\
\hline Las Vegas & 36.23 & $-25.03 \%$ & 44.20 & $-15.48 \%$ & 43.14 & -13.60 \\
\hline Miami & 48.69 & $-29.95 \%$ & 80.58 & $-18.49 \%$ & 54.55 & -14.50 \\
\hline New York & 128.35 & $-35.92 \%$ & 112.98 & $-18.03 \%$ & 132.90 & -13.89 \\
\hline Oakland & 51.76 & $-30.07 \%$ & 52.25 & $-28.09 \%$ & 55.41 & -20.36 \\
\hline Orlando & 30.68 & $-28.03 \%$ & 46.20 & $-12.52 \%$ & 41.89 & -5.09 \\
\hline San Francisco & 59.84 & $-42.49 \%$ & 57.55 & $-36.18 \%$ & 74.44 & -23.4 \\
\hline San Jose & 54.35 & $-46.77 \%$ & 64.63 & $-39.83 \%$ & 64.17 & \\
\hline
\end{tabular}

\section{Cathy A. Enz, Ph.D.}

(photo on left), is Lewis G. Schaeneman, Jr., Professor of Innovation and Dynamic Management at the Cornell University School of Hotel Administration and the Executive Director of the Center for Hospitality Research (cae4@cornell.edu). Linda Canina, Ph.D.

(photo on right), is an associate professor of finance at the Cornell University School of Hotel Administration (Ic29@cornell.edu).The authors gratefully acknowledge Smith Travel Research and the Center for Hospitality Research for making available the data used in this paper, and Hee Jung Kim for her research assistance.

(C) 2002, Cornell University
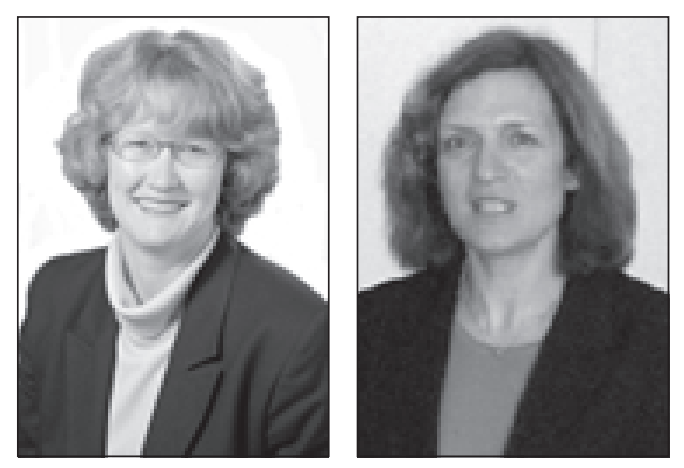

emerged into strength in the 1980s. ${ }^{7}$ Before that, market turmoil in the early 1960s closed many old-line hotels but opened the way for new concepts, including economy properties. ${ }^{8}$

While the recent experience has been painful in many ways, the harshest effects on hotel performance arising from the events of 2001 seem already to be abating. The industry's nine-year escalation of prosperity and growth during the 1990s made the recession and events of $9 / 11$ seem even more dramatic and abrupt than the industry's crash of 1991 or the morass of the 1970s. However, the data summarized in this paper show that not all regions, states, population centers, and cities were hard hit either by recession or by $9 / 11$. On the other hand, many hotels in San Jose, San Francisco, Boston, and New York continue to struggle toward recovery. The overall conclusion from the comprehensive data examined here is that U.S. hotels' performance continues to behave in a cyclical fashioneven considering the disruption of $9 / 11$. Moreover, the cycle for those that are hardest hit seems also to have the greatest amplitude, as in the case of San Francisco and New York City.

As occurs in many situations, the media portrayal of many hotels' performance exceeds the reality-in both directions. The best of times are not quite as rosy as is often reported, but by the same token the worst of times is not quite as devastating as is the reality. Nevertheless, for hotels in major cities-particularly those in the heavily populated areas of the coastal United Statesthe oscillations will continue to be wide and the ride wild. While the 9/11 tragedy handed the industry a bottom unlike any experienced by all but the most senior of managers, the lessons of time remind us that we have almost no place to go from this point but up.

\footnotetext{
${ }^{7}$ For example, see: Helen Recknagel, "1975 U.S. Travel Industry Year-end Report," Cornell Hotel and Restaurant Administration Quarterly, Vol. 16, No. 4 (February 1976), pp. 9-13; and Robert C. Lewis and Thomas J. Beggs, "Inflation: How Will the Industry Cope?," Cornell Hotel and Restaurant Administration Quarterly, Vol. 22, No. 1 (May 1981), pp. 12-18.

${ }^{8}$ See: Glenn Withiam, "Looking Back," Cornell Hotel and Restaurant Administration Quarterly, Vol. 26, No. 1 (May 1985), pp. 42-56; and Robert A. Beck, "Operation Breakthrough!," Cornell Hotel and Restaurant Administration Quarterly, Vol. 9, No. 1 (February 1969), pp. 6-23.
} 